\title{
Cilengitide (EMD 121974, NSC 707544) in asymptomatic metastatic castration resistant prostate cancer patients: A randomized phase II trial by the Prostate Cancer Clinical Trials Consortium
}

\author{
Deborah A. Bradley, MD1, Stephanie Daignault, MS1, Charles J. Ryan, MD², Robert S. \\ DiPaola, MD ${ }^{3}$, David C. Smith, MD ${ }^{1}$, Eric Small, MD², Mitchell E. Gross, MD ${ }^{4}$, Mark N. Stein, \\ $M^{3}$, Alice Chen, $\mathbf{M D}^{5}$, and Maha Hussain, MD ${ }^{1}$ \\ University of Michigan, Ann Arbor, MI \\ ${ }^{2}$ University of California, San Francisco, CA \\ ${ }^{3}$ The Cancer Institute of New Jersey, New Brunswick, NJ \\ ${ }^{4}$ Cedars-Sinai Medical Center, Los Angeles, CA \\ ${ }^{5} \mathrm{NCl} / \mathrm{CTEP}$, Bethesda, MD \\ ${ }^{6} \mathrm{MD}$ Anderson Cancer Center, Houston, TX \\ ${ }^{7}$ Immunicon Corporation, Huntingdon Valley, PA
}

\begin{abstract}
Background-Integrins are involved in prostate cancer metastasis by regulating cell adhesion, migration, invasion, motility, angiogenesis and bone metabolism. We evaluated the efficacy of two dose levels of cilengitide in patients (pts) with castrate resistant prostate cancer (CRPC).

Methods-Chemotherapy-naïve, asymptomatic metastatic CRPC pts were randomized to cilengitide $500 \mathrm{mg}$ or $2000 \mathrm{mg}$ IV twice weekly using parallel 2 -stage design. The primary endpoint was rate of objective clinical progression at six-months. Secondary endpoints included clinical and PSA response rates, safety and effects of cilengitide treatment on circulating tumor cells (CTCs) and bone remodeling markers.
\end{abstract}

\begin{abstract}
Results-Forty-four pts were accrued to first stage (22/arm). Median number of cycles was three in both arms (500mg arm: 1-8; $2000 \mathrm{mg}$ arm: 1-15). At six months, two pts (9\%) on the 500mg arm and five pts (23\%) on the $2000 \mathrm{mg}$ arm had not progressed. Best objective response was stable disease (SD) in seven pts for 9.9[8.1,20.9] months. There were three grade 3 and no grade 4 toxicities. At 12 weeks, analysis of bone markers did not reveal significant trends. At progression, bone specific alkaline phosphatase and $\mathrm{N}$-telopeptide increased in all pts, less so in pts on the $2000 \mathrm{mg}$ arm and in pts on both arms who obtained SD at 6 months. CTCs increased over time in both arms.
\end{abstract}

\footnotetext{
Corresponding Author: Maha Hussain M.D., 7314 Cancer Center, 1500 East Medical Center Drive, University of Michigan Medical Center, Ann Arbor, MI 48109-5946, Tel: (734) 936-8906, Fax: (734) 615-2719, mahahuss@umich.edu.

Authors of the DOD Prostate Cancer Clinical Trial Consortium also included Kathleen A. Cooney1, Kenneth J. Pienta, MD,1, Paul Mathew, MD,6, June Escara-Wilke, MS,1, Mahmoud Al-Hawary, MD,1, Evan Keller, DVM, PhD,1, and Gerald Doyle DDS,7

This study was presented in part at the 2007 and 2008 American Society of Clinical Oncology Annual Meeting and the 2007 Department of Defense Innovative Minds in Prostate Cancer Treatment (IMPACT 2007) Meeting.
} 
Conclusion-Cilengitide was well tolerated with modest clinical effect in favor of the higher dose. The unique trial design including a shift from response rate to objective progression as the endpoint, and not acting on PSA increases was feasible.

\section{Keywords}

prostate cancer; metastatic disease; integrins; angiogenesis; cilengitide; bone biomarkers

\section{Introduction}

Integrins are transmembrane adhesion receptors for extracellular matrix proteins that act as modulators of several key cellular functions including differentiation, survival, migration, invasion, normal and aberrant cellular growth, gene expression, and intracellular signal transduction pathways.[4,13,21,22,40,46] The functions and expression of integrins are dysregulated in several cancer types, including prostate cancer (PCa).[19,46]

PCa cells have a markedly different surrounding matrix than normal cells that is believed to be at least in part due to differential expression of integrins on tumor cells compared to nontumor cells. $[2,12,19,43,44] \alpha v \beta 3$ and $\alpha v \beta 5$ integrins are thought to be particularly important in PCa progression playing a significant role in metastasis by regulating cell adhesion, migration, invasion, motility, and angiogenesis. [5,12,19,33,35,36,43,47,48,50] $\alpha \mathrm{v} \beta 3$ integrin is also known to be critical to osteoclast migration, function and bone remodeling $[17,23,34,35,38]$ processes known to be important in establishment and progression of bony metastases.[24]

Cilengitide (Merck KGaA, Darmstadt, Germany) is a cyclic agrinine-glycine-aspartic containing peptide that binds to $\alpha v \beta 3$ and $\alpha v \beta 5$ with nanomolar affinity resulting in highly selective, competitive inhibitor of $\alpha v \beta 3$ and $\alpha v \beta 5$ integrins that in phase I studies has shown clinical activity.[18,20,28,32] Responses seen in phase I trials were achieved both at low and at higher dose levels, suggesting there may be non-linear exposure/dose-response relationships, and therefore high doses or prolonged exposure are not necessarily required. $[18,20,28,32]$ The significant role of integrins in PCa metastasis identifies integrins as an important potential target molecule for treatment of this disease. We therefore conducted a phase II trial to investigate the efficacy of two dose levels of cilengitide in patients with asymptomatic castrate-resistant prostate cancer (CRPC). Correlative studies were performed to determine the effects of integrin $\alpha v \beta 3$ and $\alpha v \beta 5$ inhibition on circulating tumor cells and systemic bone remodeling markers.

\section{Patients and Methods}

This Cancer Therapy Evaluation Program sponsored trial was conducted by the Department of Defense Prostate Cancer Clinical Trials Consortium. The protocol was reviewed and approved by the institutional review board at each participating institution and all patients provided informed consent prior to initiation of any study procedures. Eligible patients were required to have metastatic CRPC with evidence of progression by one of the following: (1.) progression of bidimensionally measurable soft tissue disease within 28 days of registration (2.) new bone lesion(s) by bone scan within 42 days of registration, and/or (3.) rising PSA with a minimum of $5 \mathrm{ng} / \mathrm{ml}$. Patients could not have PCa related pain or visceral metastasis (lung and/or liver) and were required to have an ECOG performance status of 0-2 with adequate organ function defined by a white blood count of $\geq 3,000 / \mu 1$, absolute neutrophil count $\geq 1,500 / \mu 1$, platelet count $\geq 100,000 / \mu 1$, creatinine $\leq 1.5 \times$ upper limits of normal, bilirubin within normal limits, AST and ALT $\leq 2.5 \times$ upper limits of normal. Luteinizing hormone-releasing hormone agonists were continued. Discontinuation of all nonsteroidal 
antiandrogens ( 28 days for flutamide and 42 days for bicalutamide) was required. Prior chemotherapy was not permitted. Patients could have had one prior biologic therapy (noncytotoxic). Patients on stable doses of bisphosphonates which had been started no less than six weeks prior to protocol therapy, who showed subsequent tumor progression, were permitted to continue on this medication, however, initiation of bisphosphonate therapy immediately prior or during study was not permitted. No concomitant therapy (other than LHRH agonists) to treat PCa was permitted. Men of reproductive potential had to agree to use effective contraception. Patients with a "currently active" second malignancy other than non-melanoma skin cancers were not eligible. Patients were not considered to have a "currently active" malignancy if they had completed therapy and were without evidence of disease for two years.

\section{Treatment Plan}

Patients were randomized 1:1 to either $500 \mathrm{mg}$ or $2000 \mathrm{mg}$ with stratification for bisphosphonate usage. Cilengitide was administered as a one hour intravenous infusion twice weekly per six week cycles. Toxicity was assessed using NCI-common terminology criteria version 3.0 and dose reductions were specified for grade 3 or 4 toxicities. For the $500 \mathrm{mg}$ arm, dose -1 was $400 \mathrm{mg}$ and dose -2 was $300 \mathrm{mg}$. For the $2000 \mathrm{mg}$ arm, dose -1 was $1600 \mathrm{mg}$ and dose -2 was $1200 \mathrm{mg}$. There were no planned breaks between cycles. If clinically indicated, interruption of treatment was allowed for a maximum of two weeks at a time with a maximum of two treatment interruptions.

\section{Duration of Therapy, Monitoring and Response Assessment}

In the absence of toxicity or symptomatic progression, patients were to receive a minimum of 2 cycles ( 12 weeks). Patients were monitored by history and physical exam, toxicity assessment, and PSA every 3 weeks. Response assessment by bone scan and CT scan and/or other appropriate imaging was performed every 12 weeks. Patients with symptomatic progression were removed. Patients with evidence of asymptomatic progression by CT or bone scan at first assessment ( 12 weeks) were to receive an additional cycle of treatment followed by repeat imaging 6 weeks ( 1 cycle) later. Patients with further progression were removed from protocol with time of progression recorded as first progression. Patients with stable disease or better continued therapy till further progression. PSA progression alone was not considered progression per protocol. All patients were followed until progression.

\section{End Points Definition}

Time to progression was defined as the time from the first day of treatment until the date progressive disease or death was first reported. Progression was defined by any one or more of the following parameters: 1.) Measurable disease progression by RECIST criteria. 2.) Progression by bone scan (development of $\geq 2$ new lesions). 3.) Pain progression (pain due to prostate cancer requiring intravenous, intramuscular or subcutaneous opioid therapy administered as a single dose; oral or transdermal opioid analgesic use administered for 10 out of 14 consecutive days, and/or requiring radionuclide or radiation therapy).

Measurable disease responses were defined using RECIST criteria. Bone disease response was evaluated by bone scan with disease characterized as stable or improved if no new lesions and no new pain in an area that uptake was previously visualized versus progression as defined by the appearance of two or more new skeletal lesions. PSA response was defined based on the PSA Working Group Consensus Criteria.[7] 


\section{Endpoints and Statistical Design}

The primary objective of this trial was to evaluate efficacy, as measured by the rates of objective clinical progression at six-months (not including PSA), associated14 with the two dose levels of cilengitide. The assumptions for this trial were based on the progression rates of the control arm of the randomized phase III trial testing atrasentan in a similar patient population. At the 3-month time point, the historical untreated controls with metastatic CRPC had a 50\% progression rate by bone scan[10] therefore we projected this group to have a 75\% progression rate at 6-months. It was hypothesized that cilengitide would lower this progression rate to $55 \%$ at 6-months. A modified version of the randomized selection design[45] was utilized to compare two dose levels of cilengitide, 500 $\mathrm{mg}$ and $2000 \mathrm{mg}$. Plan was for 53 patients to be randomized to each dose level using a two-stage design in a stratified manner to ensure equal percentages of prior bisphosphonate use. For each dose level, an independent evaluation was planned. If six or more of the first 20 patients were found to be progression-free at 6-months, second stage would open for that dose level and an additional 33 patients would be accrued. If 17 or fewer of the 53 patients were progression-free at 6-months, at the second stage, the dose would be considered uninteresting for further study.

Upon study completion, the planned decision rule for selecting a dose level for further study is as follows: (1) if neither arm shows activity, no arm is selected, (2) if only one arm shows activity, that arm is selected, (3) if both arms show activity and the difference in 6-month progression rates is greater than 5\%, then the arm with the highest rate is selected, (4) if both arms show activity but the difference in progression rates is less than 5\%, the selection will be based on a combination of internal and external data. This study was designed to accrue 106 total subjects, 53 per arm to allow selection of the superior dose level with $90 \%$ probability.

Secondary endpoints included objective and PSA responses, time to clinical and PSA progression, toxicities, and biological correlates. The objective response rates and 95\% confidence interval is reported. Time to clinical and PSA progression were estimated using product limit estimates of the Kaplan-Meier method. Biological correlate comparisons were tested within strata by dose level using the Wilcoxon rank test.

\section{Correlative Biology Studies}

The objective of correlative studies performed was to determine the effects of integrin $\alpha v \beta 3$ and $\alpha v \beta 5$ inhibition on total circulating tumor cells (CTCs) and endothelial cells (CECs) isolated from peripheral blood and on systemic bone remodeling markers.

Peripheral blood samples were analyzed for CTCs using the CellSearch ${ }^{\circledR}$ reagents (Immunicon Corporation, Huntington Valley, PA)[30] and for CECs using the CellTracks ${ }^{\circledR}$ reagents (Immunicon Corporation).[39] Evaluation of CTC and CEC was performed by Immunicon. Bone-specific alkaline phosphatase (BAP), an indicator of bone production was measured using a commercially available ELISA, Metra ${ }^{\circledR}$ BAP (Metra Biosystems: Quidel Corporation, Mountain View, CA), and serum N-telopeptide (NTx), a specific biochemical indicator of bone resorption using Osteomark NTX® (Wampole Laboratories, Princeton, $\mathrm{NJ})$. Intact osteocalcin $(\mathrm{OCN})$, an indicator of bone production was measured by competitive EIA ((NovoCalcin, Metra Biosystems: Quidel Corporation, Mountain View, CA).

\section{Results}

Between 1/17/05 and 1/24/07, 44 patients were registered to protocol (22 pts/arm) at five centers. Table 1 describes baseline patient characteristics by dose level. The median age was 
72 (range: $52-85$ ). $72 \%$ of patients had a performance status of 0 . Patients were well balanced between arms with the exception of a statistically significant difference with younger age (median 67 vs. 73 yrs), lower baseline PSA, (median 26 vs. 65ng/ml) and less bone progression at time of registration on the $2000 \mathrm{mg}$ arm. All patients are off protocol therapy with a median number of cycles of 3 (range $1-8$ on the 500mg arm and $1-15$ on the 2000mg arm).

\section{Adverse Events}

Therapy was very well tolerated with no grade 4 or greater adverse events (AEs) and only three grade 3 AEs (neutropenia, and transient lymph node pain and enlargement in one patient). Table 2 describes in detail AEs by type and grade by dose level. Only one patient required dose reduction to -1 dose level.

\section{Efficacy Results}

At the time of interim analysis after first stage of accrual, 91\% (95\% CI (71-99\%) of patients on the $500 \mathrm{mg}$ arm had progressed at the 6 month assessment $(2 / 22$ pts not progressing) and $77 \%$ (55- 92\%) on the 2000mg dose arm (5/22 pts not progressing) (Figure 1.)

Best response obtained was stable disease (SD). Overall there were 15 pts with SD as their best response at any time during the trial (median 6.9 months, range [2.8,20.9]), however per protocol specified requirement of SD at 6 months, 7 fulfilled the criteria ( median 9.9 months, range $[8.1,20.9]$. There was no significant difference in median duration of SD between arms ( $\mathrm{p}=0.95)(2000 \mathrm{mg}(\mathrm{n}=9)$ duration $\mathrm{SD}=8.1$ months; $500 \mathrm{mg}$ arm $(\mathrm{n}=6)$ duration $\mathrm{SD}=6.9$ months) although the study was not designed to compare arms. Twentyseven patients had asymptomatic progression at first assessment (12 weeks). Of these 27 patients, $13(48 \%)$ elected to continue treatment per protocol. $31 \%$ of these 13 patients achieved a best response of SD, 69\% experienced confirmed progression. These patients remained on treatment for a median of one additional cycle (range 1-3).

There was one PSA response on the 2000mg arm and none on the 500mg arm. At first assessment, 4/44 (9\%) of patients had a stable PSA. Median time to PSA progression was 0.7 months $(95 \%$ CI $0.7,1.4)$ on the $500 \mathrm{mg}$ arm and 2.3 months $(95 \%$ CI $1.3,4.2)$ on the $2000 \mathrm{mg}$ arm $(\mathrm{p}=0.0001)$. There was no significant correlation between baseline PSA or baseline bone markers and study-defined objective or PSA progression.

All patients are off study; five (11\%) withdrew consent, 34 (77\%) secondary to progression [19 (56\%) in bone, $14(44 \%)$ in soft tissue] and $5(11 \%)$ for other reasons. In an exploratory analysis of the 34 patients who had progression by objective and PSA criteria, study defined objective progression occurred at a median of 1.9 months (range: $-1.5-9.2$ months) after PSA progression.

\section{Correlative Studies}

There were no significant differences between arms at baseline in serum bone markers BAP, NTX, and OCN with the exception that OCN was higher in the 500mg arm in patients not receiving zoledronic acid (Table 3.). OCN was most likely higher in patients not receiving zoledronic acid due to increased bone turnover in these patients. There were no significant biologic trends at first assessment (12 weeks). At time of progression, BAP and NTX increased in all patients, however less so in patients on the $2000 \mathrm{mg}$ arm and in patients on both arms who obtained SD at 6 months. 
Samples for assessment of CTCs and CECs were available for all patients at baseline. At week 12, samples were available for 32 pts for CTC and 28 pts for CEC assessment. Histograms did not differ by dose level (Figure 2). Time to progression (TTP) was not different between patients with 0-5 CTCs at baseline compared to those with $>5$ CTCs at baseline. TTP was slightly better for the group with 0-5 CTCs at cycle 2 compared to those with $>5$ CTCs. This was not statistically significant. The group of patients with a decrease in CTCs at cycle 2 compared to baseline had a slight advantage in TTP compared to those whose CTCs increased between baseline and cycle 2 . This was not statistically significant. There was no correlation between CEC number and progression.

\section{Discussion}

We evaluated two dose levels of cilengitide, an inhibitor of $\alpha v \beta 3$ and $\alpha v \beta 5$ integrins, in chemotherapy naïve patients with asymptomatic, metastatic CRPC using a six month nonprogression endpoint. The choice of this endpoint represents a shift in paradigm from using PSA decline rates or response rates to a clinically meaningful endpoint. The rational was further supported by the hypothesized cytostatic mechanism of action. Recognizing the difficulties in interpreting early changes, this trial pioneered a trial design that allowed patients with evidence of asymptomatic progression at first assessment to continue on study with an interim follow up scan to confirm progression. Both approaches proved feasible.

Since neither arm, at the time of prespecified interim analysis (after first stage of accrual), met the prespecified cutoff of $6(27 \%)$ or more patients progression free at the six month evaluation, the study did not proceed to second stage. Although neither arm reached the prespecified activity level, clinical (a trend towards less progression at the six month assessment; $91 \%$ and $77 \%$ on the $500 \mathrm{mg}$ arm and the $2000 \mathrm{mg}$ dose arm, respectively) and correlative studies results suggest that the $2000 \mathrm{mg}$ dose level has more but modest activity over the $500 \mathrm{mg}$ dose.

Markers of bone turnover are indicative of bone resorption and formation reflecting osteoclastic and osteoblastic activity, respectively and are proving to be a useful tool for measuring the efficacy of bone targeted therapy.[8,9,26,49] Increased N-telopeptide and bone specific alkaline phosphatase have been associated with adverse clinical outcomes, including shorter time to skeletal events, disease progression and death.[6,11,27,41] In this trial, bone turnover markers of patients treated on the $2000 \mathrm{mg}$ arm tended not to increase as much at time of progression although was not statistically significant. Additionally, patients on both arms that obtained stable disease at six months showed a similar trend suggesting an effect of cilengitide on the bone microenvironment in some patients. Another promising biomarker in CRPC investigated in this study is CTCs. Recent studies of CTCs in CRPC have evaluated the ability of CTCs to be used as a surrogate for overall survival. $[14,16,29,30]$ Less than $5 \mathrm{CTCs} / 7.5 \mathrm{~mL}$ at baseline and post-treatment has correlated with improved overall survival. In this study, there was a trend towards increased time to progression in patients on the $2000 \mathrm{mg}$ dose arm with less than or equal to five CTCs at first assessment. In all patients, there was a non-significant trend towards increased time to progression in patients with 0-5 CTCs at cycle 2 compared to those with $>5$ CTCs at cycle 2 , again suggestive of possible activity in some patients though the numbers are too small for any major conclusion.

It is possible that significant clinical activity was not demonstrated despite a signal of biologic activity because of incomplete integrin inhibition which could have been impacted by dose or schedule. In phase I testing, no clear pattern of cilengitide toxicity could be determined and no maximum tolerated dose was reached $[18,28,32]$ with responses achieved at both low and high dose levels.[1,18,20,28,32] However, disease specific phase II testing 
points towards a modest increased efficacy at higher dose levels $[32,37]$ which is supported in our current trial. In a phase IIa study investigating 500mg and 2000mg dosing in patients with recurrent glioblastoma,[37] pharmacokinetic studies revealed significantly greater exposures among the 2000mg cohort. However, in prostate cancer, which is not known to be as vascular as brain tumors, it is possible that even the $2000 \mathrm{mg}$ dose may not have been sufficient to effectively block integrin receptors to result in a biologic effect due to the short plasma half-life of cilengitide of 2.5-4 hours.[28,32] Therefore dosing chosen for this trial may not have been optimal with the potential need for continuous infusion or more frequent administration to observe a significant biologic effect. It is also possible that alternative integrins not blocked by cilengitide may have a more significant role in prostate cancer. To date, the specific functions of integrins, their ligands, and their modulators in prostate cancer progression are incompletely understood. $[3,15,19,25,31,33,43]$ This study suggests that inhibition of integrins may have some biologic effect but perhaps alternative or more inhibition is necessary. Because tumors can overcome integrin requirements through upregulation of integrin-initiated intracellular signaling pathways, inhibition of integrindependent signaling components, including FAK, Src, and P13K may serve as complimentary chemotherapeutic targets[46]

Because of the lessons learned investigating other bone targeted therapies suggesting patients may have been taken off therapy prematurely, we pioneered this study design to avoid premature withdrawal of the agent. Patients were permitted to continue on trial until confirmed progression. Twenty-five patients had asymptomatic progression at first assessment (12 weeks). Of these 24 patients, 13 (54\%) elected to continue treatment. Thirtyone percent of these 13 patients achieved a best response of SD. 69\% experienced confirmed progression at the second assessment after cycle 3 (18 weeks). This is one of the first trials to test the feasibility of this concept. Since this trial was designed in 2004, the Prostate Cancer Clinical Trials Working Group has published consensus recommendations for clinical trial conduct including this concept.[42]

\section{Conclusions}

In summary, cilengitide was well tolerated, however, did not meet the protocol prespecified decrease in the six month progression rate at either dose level. The clinical and biomarker results suggest a potential improved, though, modest effect with the $2000 \mathrm{mg}$ dose. The findings from this study therefore support further investigation of integrin inhibition with more active agents in this disease.

\section{Acknowledgments}

CTEP, Prostate SPORE Grant P50 CA069568-09, Merck KGaA, PC051382, PC051375, PCF N008367, Immunicon Corporation,

\section{References}

1. EMD 121974 Cilengitide, cyclo-[Arg-Gly-Asp-DPhe-(NMeVal)]. Investigator's Brochure.

2. Albelda SM. Role of integrins and other cell adhesion molecules in tumor progression and metastasis. Lab Invest. 1993; 68:4-17. [PubMed: 8423675]

3. Allen MV, Smith GJ, Juliano R, Maygarden SJ, Mohler JL. Downregulation of the beta4 integrin subunit in prostatic carcinoma and prostatic intraepithelial neoplasia. Hum Pathol. 1998; 29:311318. [PubMed: 9563778]

4. Assoian RK, Schwartz MA. Coordinate signaling by integrins and receptor tyrosine kinases in the regulation of G1 phase cell-cycle progression. Curr Opin Genet Dev. 2001; 11:48-53. [PubMed: 11163150] 
5. Brooks PC, Montgomery AM, Rosenfeld M, Reisfeld RA, Hu T, Klier G, Cheresh DA. Integrin alpha $\mathrm{v}$ beta 3 antagonists promote tumor regression by inducing apoptosis of angiogenic blood vessels. Cell. 1994; 79:1157-1164. [PubMed: 7528107]

6. Brown JE, Cook RJ, Major P, Lipton A, Saad F, Smith M, Lee KA, Zheng M, Hei YJ, Coleman RE. Bone turnover markers as predictors of skeletal complications in prostate cancer, lung cancer, and other solid tumors. J Natl Cancer Inst. 2005; 97:59-69. [PubMed: 15632381]

7. Bubley GJ, Carducci M, Dahut W, Dawson N, Daliani D, Eisenberger M, Figg WD, Freidlin B, Halabi S, Hudes G, Hussain M, Kaplan R, Myers C, Oh W, Petrylak DP, Reed E, Roth B, Sartor O, Scher H, Simons J, Sinibaldi V, Small EJ, Smith MR, Trump DL, Wilding G, et al. Eligibility and response guidelines for phase II clinical trials in androgen-independent prostate cancer: recommendations from the Prostate-Specific Antigen Working Group. J Clin Oncol. 1999; 17:3461-3467. [PubMed: 10550143]

8. Carducci M, Nelson JB, Saad F, Schulman CC, Dearnaley DP, Sleep DJ, Hulting SM, Isaacson JD, Allen A, Nisen P. Effects of atrasentan on disease progression and biological markers in men with metastatic hormone-refractory prostate cancer: Phase 3 study. J Clin Oncol. 2004; 22:4508.

9. Carducci MA, Padley RJ, Breul J, Vogelzang NJ, Zonnenberg BA, Daliani DD, Schulman CC, Nabulsi AA, Humerickhouse RA, Weinberg MA, Schmitt JL, Nelson JB. Effect of endothelin-A receptor blockade with atrasentan on tumor progression in men with hormone-refractory prostate cancer: a randomized, phase II, placebo-controlled trial. J Clin Oncol. 2003; 21:679-689. [PubMed: 12586806]

10. Carducci MA, Saad F, Abrahamsson PA, Dearnaley DP, Schulman CC, North SA, Sleep DJ, Isaacson JD, Nelson JB. A phase 3 randomized controlled trial of the efficacy and safety of atrasentan in men with metastatic hormone-refractory prostate cancer. Cancer. 2007; 110:19591966. [PubMed: 17886253]

11. Coleman RE, Major P, Lipton A, Brown JE, Lee KA, Smith M, Saad F, Zheng M, Hei YJ, Seaman J, Cook R. Predictive value of bone resorption and formation markers in cancer patients with bone metastases receiving the bisphosphonate zoledronic acid. J Clin Oncol. 2005; 23:4925-4935. [PubMed: 15983391]

12. Cooper CR, Chay CH, Pienta KJ. The role of alpha(v)beta(3) in prostate cancer progression. Neoplasia. 2002; 4:191-194. [PubMed: 11988838]

13. Cooper CR, Pienta KJ. Cell adhesion and chemotaxis in prostate cancer metastasis to bone: a minireview. Prostate Cancer Prostatic Dis. 2000; 3:6-12. [PubMed: 12497155]

14. Danila DC, Heller G, Gignac GA, Gonzalez-Espinoza R, Anand A, Tanaka E, Lilja H, Schwartz L, Larson S, Fleisher M, Scher HI. Circulating tumor cell number and prognosis in progressive castration-resistant prostate cancer. Clin Cancer Res. 2007; 13:7053-7058. [PubMed: 18056182]

15. Davis TL, Cress AE, Dalkin BL, Nagle RB. Unique expression pattern of the alpha6beta4 integrin and laminin-5 in human prostate carcinoma. Prostate. 2001; 46:240-248. [PubMed: 11170153]

16. de Bono JS, Scher HI, Montgomery RB, Parker C, Miller MC, Tissing H, Doyle GV, Terstappen LW, Pienta KJ, Raghavan D. Circulating tumor cells predict survival benefit from treatment in metastatic castration-resistant prostate cancer. Clin Cancer Res. 2008; 14:6302-6309. [PubMed: 18829513]

17. Duong LT, Lakkakorpi P, Nakamura I, Rodan GA. Integrins and signaling in osteoclast function. Matrix Biol. 2000; 19:97-105. [PubMed: 10842093]

18. Eskens FA, Dumez H, Hoekstra R, Perschl A, Brindley C, Bottcher S, Wynendaele W, Drevs J, Verweij J, van Oosterom AT. Phase I and pharmacokinetic study of continuous twice weekly intravenous administration of Cilengitide (EMD 121974), a novel inhibitor of the integrins alphavbeta3 and alphavbeta5 in patients with advanced solid tumours. Eur J Cancer. 2003; 39:917-926. [PubMed: 12706360]

19. Fornaro M, Manes T, Languino LR. Integrins and prostate cancer metastases. Cancer Metastasis Rev. 2001; 20:321-331. [PubMed: 12085969]

20. Hariharan S, Gustafson D, Holden S, McConkey D, Davis D, Morrow M, Basche M, Gore L, Zang C, O'Bryant CL, Baron A, Gallemann D, Colevas D, Eckhardt SG. Assessment of the biological and pharmacological effects of the alpha nu beta3 and alpha nu beta5 integrin receptor antagonist, cilengitide (EMD 121974), in patients with advanced solid tumors. Ann Oncol. 2007; 18:14001407. [PubMed: 17693653] 
21. Holly SP, Larson MK, Parise LV. Multiple roles of integrins in cell motility. Exp Cell Res. 2000; 261:69-74. [PubMed: 11082276]

22. Hood JD, Cheresh DA. Role of integrins in cell invasion and migration. Nat Rev Cancer. 2002; 2:91-100. [PubMed: 12635172]

23. Hughes DE, Salter DM, Dedhar S, Simpson R. Integrin expression in human bone. J Bone Miner Res. 1993; 8:527-533. [PubMed: 8511980]

24. Keller ET, Brown J. Prostate cancer bone metastases promote both osteolytic and osteoblastic activity. J Cell Biochem. 2004; 91:718-729. [PubMed: 14991763]

25. Knox JD, Cress AE, Clark V, Manriquez L, Affinito KS, Dalkin BL, Nagle RB. Differential expression of extracellular matrix molecules and the alpha 6-integrins in the normal and neoplastic prostate. Am J Pathol. 1994; 145:167-174. [PubMed: 8030747]

26. Lara PN Jr, Stadler WM, Longmate J, Quinn DI, Wexler J, Van Loan M, Twardowski P, Gumerlock PH, Vogelzang NJ, Vokes EE, Lenz HJ, Doroshow JH, Gandara DR. A randomized phase II trial of the matrix metalloproteinase inhibitor BMS-275291 in hormone-refractory prostate cancer patients with bone metastases. Clin Cancer Res. 2006; 12:1556-1563. [PubMed: 16533781]

27. Lipton A, Cook R, Saad F, Major P, Garnero P, Terpos E, Brown JE, Coleman RE. Normalization of bone markers is associated with improved survival in patients with bone metastases from solid tumors and elevated bone resorption receiving zoledronic acid. Cancer. 2008; 113:193-201. [PubMed: 18459173]

28. MacDonald TJ, Stewart CF, Kocak M, Goldman S, Ellenbogen RG, Phillips P, Lafond D, Poussaint TY, Kieran MW, Boyett JM, Kun LE. Phase I clinical trial of cilengitide in children with refractory brain tumors: Pediatric Brain Tumor Consortium Study PBTC-012. J Clin Oncol. 2008; 26:919-924. [PubMed: 18281665]

29. Moreno J, DeBono JS, Shaffer D, Montgomery B, Miller MC, Tissing H, Doyle G, Terstappen LW, Pienta KJ, Raghavan D. Multi-center study evaluating circulating tumor cells (CTCs) as a surrogate for survival in men treated for castration refractory prostate cancer (CRPC). Journal of Clinical Oncology. 2007; 25 abstract 5016.

30. Moreno JG, Miller MC, Gross S, Allard WJ, Gomella LG, Terstappen LW. Circulating tumor cells predict survival in patients with metastatic prostate cancer. Urology. 2005; 65:713-718. [PubMed: 15833514]

31. Murant SJ, Handley J, Stower M, Reid N, Cussenot O, Maitland NJ. Co-ordinated changes in expression of cell adhesion molecules in prostate cancer. Eur J Cancer. 1997; 33:263-271. [PubMed: 9135498]

32. Nabors LB, Mikkelsen T, Rosenfeld SS, Hochberg F, Akella NS, Fisher JD, Cloud GA, Zhang Y, Carson K, Wittemer SM, Colevas AD, Grossman SA. Phase I and correlative biology study of cilengitide in patients with recurrent malignant glioma. J Clin Oncol. 2007; 25:1651-1657. [PubMed: 17470857]

33. Nagle RB, Knox JD, Wolf C, Bowden GT, Cress AE. Adhesion molecules, extracellular matrix, and proteases in prostate carcinoma. J Cell Biochem Suppl. 1994; 19:232-237. [PubMed: 7823596]

34. Nakamura I, Pilkington MF, Lakkakorpi PT, Lipfert L, Sims SM, Dixon SJ, Rodan GA, Duong LT. Role of alpha(v)beta(3) integrin in osteoclast migration and formation of the sealing zone. J Cell Sci. 1999; 112(Pt 22):3985-3993. [PubMed: 10547359]

35. Nemeth JA, Cher ML, Zhou Z, Mullins C, Bhagat S, Trikha M. Inhibition of alpha(v)beta3 integrin reduces angiogenesis, bone turnover, and tumor cell proliferation in experimental prostate cancer bone metastases. Clin Exp Metastasis. 2003; 20:413-420. [PubMed: 14524530]

36. Pidgeon GP, Tang K, Cai YL, Piasentin E, Honn KV. Overexpression of platelet-type 12lipoxygenase promotes tumor cell survival by enhancing alpha(v)beta(3) and alpha(v)beta(5) integrin expression. Cancer Res. 2003; 63:4258-4267. [PubMed: 12874035]

37. Reardon D, Fink K, Nabors B, Cloughesy T, Plotkin S, Schiff D, Raizer J, Krueger S, Picard M, Mikkelsen T. Phase IIa trial of cilengitide (EMD121974) single-agent therapy in patients (pts) with recurrent glioblastoma (GBM): EMD 121974-009. Journal of Clinical Oncology. 2007; 25 abstract 2002 . 
38. Rodan SB, Rodan GA. Integrin function in osteoclasts. J Endocrinol. 1997; 154 Suppl:S47-S56. [PubMed: 9379137]

39. Rowand JL, Martin G, Doyle GV, Miller MC, Pierce MS, Connelly MC, Rao C, Terstappen LW. Endothelial cells in peripheral blood of healthy subjects and patients with metastatic carcinomas. Cytometry A. 2007; 71:105-113. [PubMed: 17226859]

40. Ruoslahti E, Reed JC. Anchorage dependence, integrins, and apoptosis. Cell. 1994; 77:477-478. [PubMed: 8187171]

41. Saad F, Gleason DM, Murray R, Tchekmedyian S, Venner P, Lacombe L, Chin JL, Vinholes JJ, Goas JA, Chen B. A randomized, placebo-controlled trial of zoledronic acid in patients with hormone-refractory metastatic prostate carcinoma. J Natl Cancer Inst. 2002; 94:1458-1468. [PubMed: 12359855]

42. Scher HI, Halabi S, Tannock I, Morris M, Sternberg CN, Carducci MA, Eisenberger MA, Higano C, Bubley GJ, Dreicer R, Petrylak D, Kantoff P, Basch E, Kelly WK, Figg WD, Small EJ, Beer TM, Wilding G, Martin A, Hussain M. Design and end points of clinical trials for patients with progressive prostate cancer and castrate levels of testosterone: recommendations of the Prostate Cancer Clinical Trials Working Group. J Clin Oncol. 2008; 26:1148-1159. [PubMed: 18309951]

43. Schmelz M, Cress AE, Scott KM, Burger F, Cui H, Sallam K, McDaniel KM, Dalkin BL, Nagle RB. Different phenotypes in human prostate cancer: alpha6 or alpha3 integrin in cell-extracellular adhesion sites. Neoplasia. 2002; 4:243-254. [PubMed: 11988844]

44. Shah RB, Mehra R, Chinnaiyan AM, Shen R, Ghosh D, Zhou M, Macvicar GR, Varambally S, Harwood J, Bismar TA, Kim R, Rubin MA, Pienta KJ. Androgen-independent prostate cancer is a heterogeneous group of diseases: lessons from a rapid autopsy program. Cancer Res. 2004; 64:9209-9216. [PubMed: 15604294]

45. Simon R, Wittes RE, Ellenberg SS. Randomized phase II clinical trials. Cancer Treat Rep. 1985; 69:1375-1381. [PubMed: 4075313]

46. Slack-Davis JK, Parsons JT. Emerging views of integrin signaling: implications for prostate cancer. J Cell Biochem. 2004; 91:41-46. [PubMed: 14689580]

47. Stewart DA, Cooper CR, Sikes RA. Changes in extracellular matrix (ECM) and ECM-associated proteins in the metastatic progression of prostate cancer. Reprod Biol Endocrinol. 2004; 2:2. [PubMed: 14711377]

48. Tantivejkul K, Kalikin LM, Pienta KJ. Dynamic process of prostate cancer metastasis to bone. J Cell Biochem. 2004; 91:706-717. [PubMed: 14991762]

49. Vogelzang N, Nelson J, Schulman C, Dearnaley D, Saad F, Sleep D, Isaacson J, Carducci M. Meta-analysis of clinical trials of atrasentan $10 \mathrm{mg}$ in metastatic hormone-refractory prostate cancer. J Clin Oncol. 2005; 23:4563.

50. Zheng DQ, Woodard AS, Fornaro M, Tallini G, Languino LR. Prostatic carcinoma cell migration via alpha(v)beta3 integrin is modulated by a focal adhesion kinase pathway. Cancer Res. 1999; 59:1655-1664. [PubMed: 10197643] 


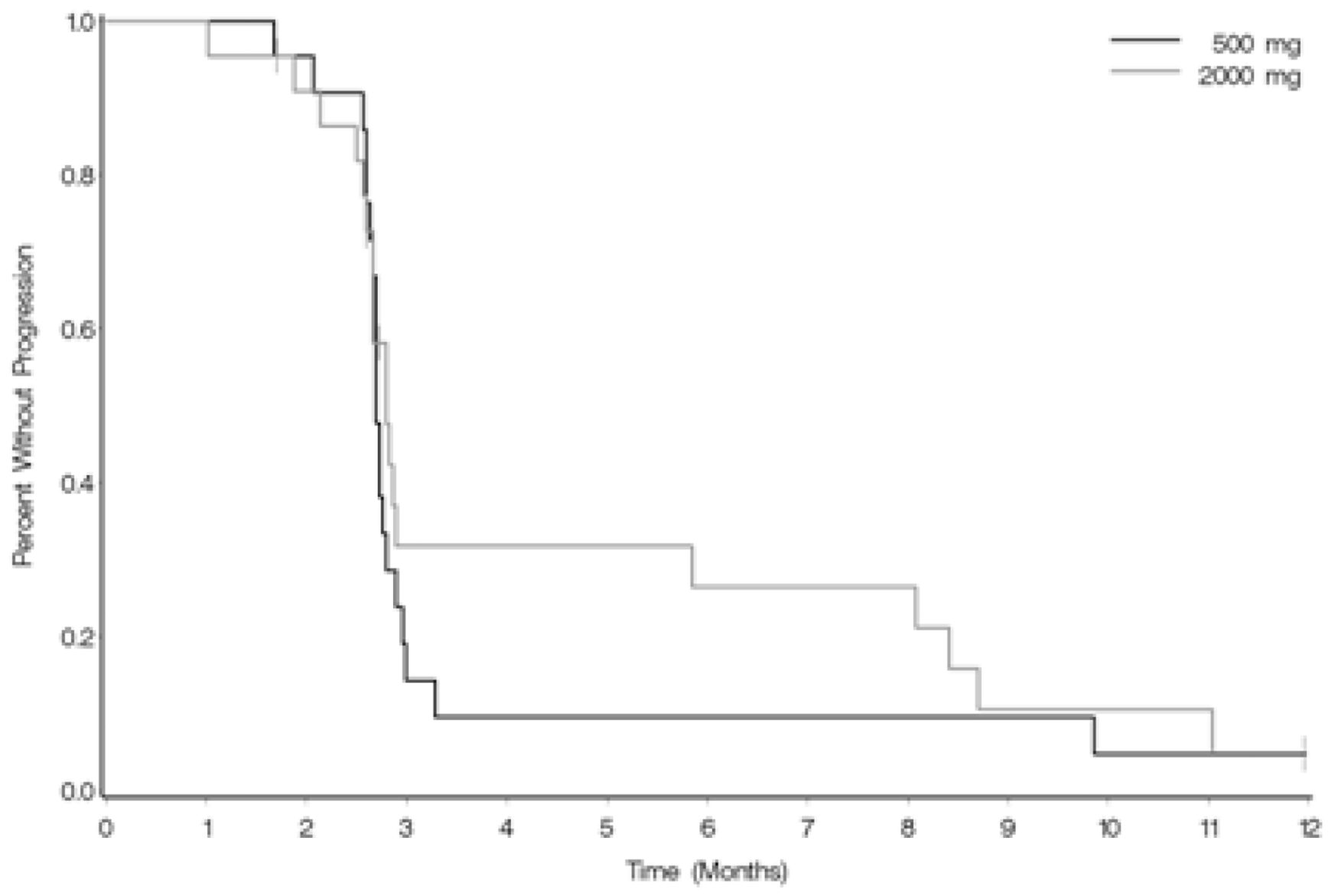

Figure 1. Time to Objective Progression

Progression at 6 months: $\quad 500 \mathrm{mg}$ : $91 \%$ (2/22 pts not progressing)

2000mg: $77 \%$ (5/22 pts not progressing)

Median time to progression was 2.7 months $(95 \%$ CI $2.66,2.79)$ on the $500 \mathrm{mg}$ arm and .8 months $(95 \%$ CI $2.66,5.85)$ on the $2000 \mathrm{mg}$ arm (log-rank p-value $=0.52)$ 

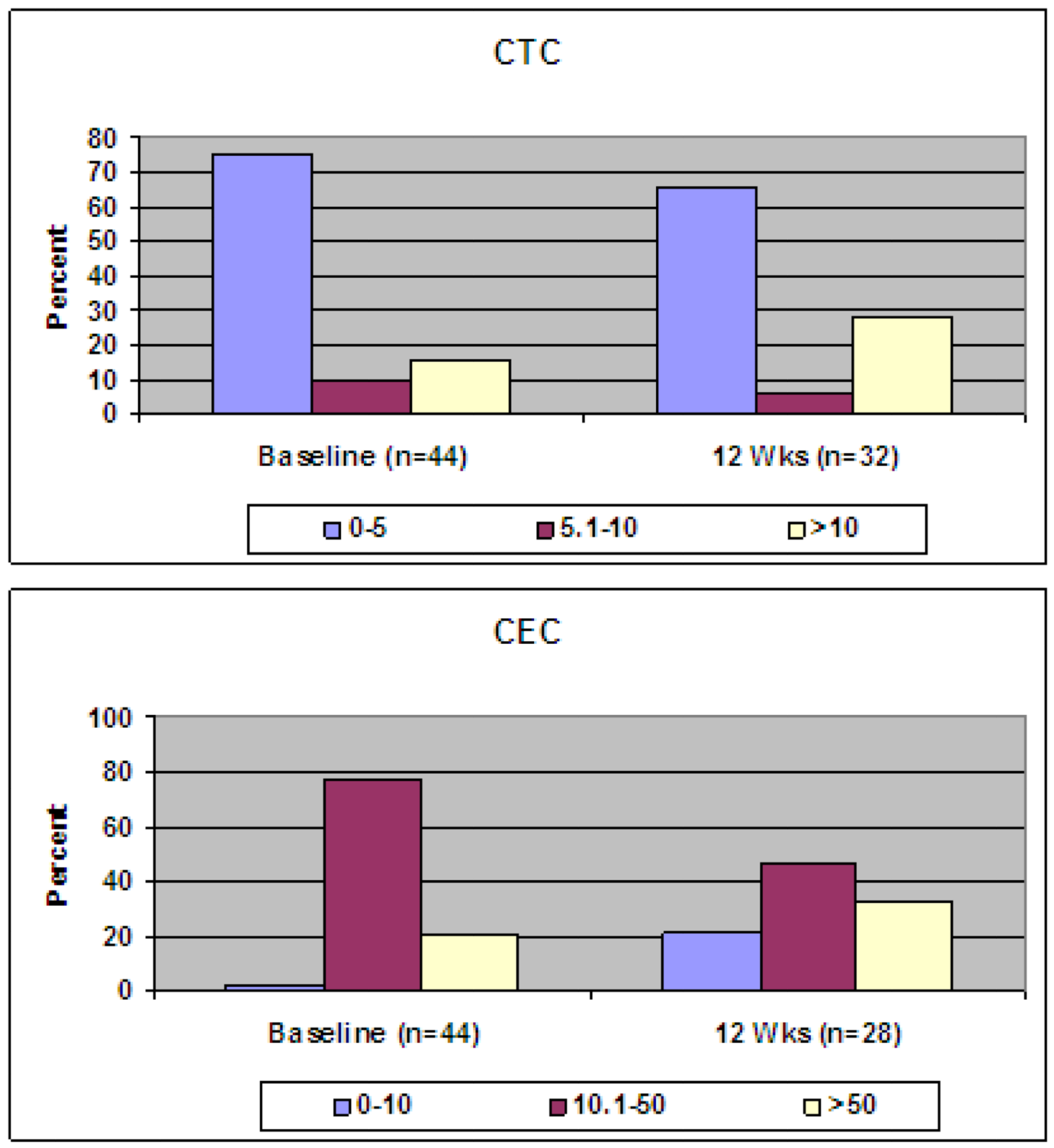

Figure 2. Histogram of Circulating Tumor Cells/Circulating Endothelial Cells 
Table 1

Baseline Patient Characteristics

\begin{tabular}{|c|c|c|}
\hline & $500 \mathrm{mg}(\mathrm{n}=22)$ & $2000 \mathrm{mg}(\mathrm{n}=22)$ \\
\hline \multicolumn{3}{|l|}{ Age } \\
\hline Median & $73(59-84)$ & $67(52-85)$ \\
\hline \multicolumn{3}{|l|}{ Race } \\
\hline White & 18 & 20 \\
\hline African American & 2 & 2 \\
\hline Asian & 2 & 0 \\
\hline \multicolumn{3}{|l|}{ Performance Status } \\
\hline $\mathbf{0}$ & 16 & 15 \\
\hline 1 & 6 & 6 \\
\hline Unknown & 0 & 1 \\
\hline Zoledronic Acid Usage* & $6(27 \%)$ & $5(23 \%)$ \\
\hline \multicolumn{3}{|l|}{ PSA (ng/ml) } \\
\hline Median & $65(6-870)$ & $26(5-621)$ \\
\hline \multicolumn{3}{|c|}{ Disease Progression at Registration } \\
\hline PSA & $21(95 \%)$ & $19(86 \%)$ \\
\hline Soft Tissue & $5(23 \%)$ & $11(50 \%)$ \\
\hline Bone & $13(59 \%)$ & $3(14 \%)$ \\
\hline
\end{tabular}

Zoledronic acid was permitted if started $\geq 6$ weeks prior to registration 
Table 2

Treatment Related Adverse Events

\begin{tabular}{|l|c|c|c|}
\hline Adverse Event & Grade & 500mg & 2000mg \\
\hline Lymph node pain & 3 & 1 & 0 \\
\hline Lymphatics-other & 3 & 1 & 0 \\
\hline$\downarrow$ Neutrophil count & 3 & 0 & 1 \\
\hline Anorexia & 2 & 2 & 0 \\
\hline Arthritis & 2 & 0 & 1 \\
\hline Bone pain & 2 & 1 & 0 \\
\hline Constipation & 2 & 1 & 1 \\
\hline Dehydration & 2 & 1 & 0 \\
\hline Fatigue & 2 & 4 & 3 \\
\hline Glucose tolerance impaired & 2 & 1 & 0 \\
\hline Headache & 2 & 0 & 1 \\
\hline$\downarrow$ Hemoglobin & 2 & 0 & 2 \\
\hline Hyperglycemia & 2 & 0 & 1 \\
\hline Hypoalbuminemia & 2 & 0 & 1 \\
\hline Hypotension & 2 & 1 & 0 \\
\hline Leukopenia & 2 & 1 & 0 \\
\hline Musculoskeletal disorder & 2 & 0 & 1 \\
\hline Nausea & 2 & 1 & 0 \\
\hline$\downarrow$ Neutrophil count & 2 & 1 & 1 \\
\hline Pain in extremity & 2 & 1 & 0 \\
\hline Tooth infection & 2 & 0 & 1 \\
\hline
\end{tabular}

Includes all grade 2 and above toxicities considered possible, likely, or probably related to cilengitide. 
